\title{
Osteonecrosis of the head of femur in a Nigerian teaching hospital
}

\author{
*Thanni L.O., Gbadegesin S.A., Adebanjo A.A., Osundina B.A., Olushiyan B.F.
}

\begin{abstract}
Objective: Osteonecrosis $(\mathrm{ON})$ of the head of femur is not uncommon. The characteristics of affected patients and the associated aetiological factors in Nigeria are largely undocumented. To determine the epidemiological characteristics of patients with osteonecrosis of the head of femur, the radiological severity at presentation and associated aetiological risk factors
\end{abstract}

Methods: A retrospective study was done, of patients with femoral head ON seen between January 2013 and January 2019. Data on patients' characteristics, affected hips and radiological severity were entered onto a proforma and analysed.

Results: There were 29 patients with ON of the head of femur involving 32 hips. There were $55.2 \%$ females and $44.8 \%$ male patients. While $3(10.3 \%)$ patients had bilateral affectation, $26(89.7 \%)$ had unilateral affectation. Their mean age is 26.6 years \pm 13.3 . The mean age of male and female patients are 29.3 years and 24.3 years respectively. The mean BMI is $21.9 \pm 5.2$ and no significant difference in the BMI of both genders, $\mathrm{p}=0.74$. Ninety percent of them presented with advanced radiographic stages. Factors found to be associated with ON are sickle cell disease (SCD) 44.8\%, trauma 13.8\%, CVA 3.4\% and idiopathic cases $37.7 \%$. There is no significant difference in the frequency of unilateral and bilateral occurrence in the groups with different hemoglobin genotypes.

Conclusions: Osteonecrosis of the head of femur occurs more often in young patients. They present late, with collapse of the head of femur. SCD, especially HbSS is the most common associated risk factor followed by idiopathic cases.

Key words: Osteonecrosis, avascular necrosis, head of femur, sickle cell disease, risk factors

*Correspondence author

Thanni L.O.A.

http://orcid.org/0000-0003-0619-2042

Email: loathanni@yahoo.com

${ }^{1}$ Department of Orthopaedics and Traumatology, Olabisi Onabanjo University Teaching Hospital, Sagamu, Nigeria

${ }^{2}$ Department of Orthopaedics, University of Medical Sciences Teaching Hospital Complex, Laje, Nigeria 


\title{
Ostéonécrose de la tête du fémur dans un hôpital universitaire Nigérian
}

\author{
*Thanni L.O., Gbadegesin S.A., Adebanjo A.A., Osundina B.A., Olushiyan B.F.
}

\begin{abstract}
Résumé
Objectif: L'ostéonécrose $(\mathrm{ON})$ de la tête du fémur n'est pas rare. Les caractéristiques des patients affectés et les facteurs étiologiques associés au Nigeria sont largement non documentés. Déterminer les caractéristiques épidémiologiques des patients atteints d'ostéonécrose de la tête du fémur, la gravité radiologique à la présentation et les facteurs de risque étiologiques associés
\end{abstract}

Méthodes : Une étude rétrospective a été faite, des patients avec la tête fémorale observée entre janvier 2013 et janvier 2019 a été fait. Les données sur les caractéristiques des patients, les hanches affectées et la gravité radiologique ont été saisies sur un formulaire et analysées.

Résultats : Il y avait 29 patients avec ON de la tête du fémur impliquant 32 hanches. Il y avait $55,2 \%$ de femmes et $44,8 \%$ de patients masculins. Alors que $3(10,3 \%)$ patients avaient une affectation bilatérale, 26 $(89,7 \%)$ avaient une affectation unilatérale. Leur âge moyen est de $26.6 \pm 13.3$ L'âge moyen des patients masculins et féminins est de 29,3 ans et 24,3 ans respectivement. L'IMC moyen est de 21.9 \pm 5.2 et aucune différence significative dans l'IMC des deux sexes, $p=0,74$. Quatre - vingt dix pour cent d'entre eux a présenté au stade radiographique avancé. Les facteurs associés à l'ON sont la drépanocytose (SCD) $44,8 \%$, traumatismes $13,8 \%$, AVC 3,4\% et cas idiopathiques $37,7 \%$. Il n'y a pas de différence significative entre la fréquence d'occurrence unilatérale et bilatérale dans les groupes avec différents génotypes d'hémoglobine.

Conclusion : L'ostéonécrose de la tête du fémur survient plus souvent chez les jeunes patients. Ils se présentent tardivement, avec effondrement de la tête du fémur. La drépanocytose, en particulier l'HbSS, est le facteur de risque associé le plus courant, suivi des cas idiopathiques.

Mots - clés : Ostéonécrose, nécrose avasculaire, tête du fémur, drépanocytose, facteurs de risque

*Auteur Correspondant

Thanni L.O.A.

http://orcid.org/0000-0003-0619-2042

Email:loathanni@yahoo.com

'Department of Orthopaedics and Traumatology, Olabisi Onabanjo University Teaching Hospital, Sagamu, Nigeria

${ }^{2}$ Department of Orthopaedics, University of Medical Sciences Teaching Hospital Complex, Laje, Nigeria 


\section{INTRODUCTION}

Osteonecrosis, also referred to as avascular necrosis (AVN) and aseptic necrosis is a pathologic condition resulting from interruption of blood to bone and its marrow. Although this condition can affect various anatomic bone parts such as the condyles of the femur (knee), head of humerus (shoulder) and the talus (ankle), the most common site of affectation is the head of femur $(1,2,3,4)$. The ischaemic insult that causes death of osteocytes, also activates osteoclasts to resorb affected subchondral bone (5). Evolution to collapse of the head of femur is therefore natural, leading to devastating consequences of functional impairment. This impairment is worse in patients with bilateral hip involvement (6). According to Osawa et al (6), patient-reported quality of life in patients with bilateral hip disease is worse compared with those who have unilateral affectation. Children with sickle cell disease and $\mathrm{ON}$ of the head of femur have been shown to have lower quality of life scores globally as well as in physical functioning and school functioning areas (7).

Preventing progression to collapse is an important major challenge to orthopaedic surgeons. To achieve this, there is a need to understand the characteristics of the affected patients and nature of the disease in our patients so that we can institute measures of early detection and prevention of progression to collapse where possible.

In Nigeria, epidemiological studies on osteonecrosis of the head of femur in general are not available. Therefore, the nature of the condition, patient characteristics and outcomes are largely unknown. The very few available studies are limited to patients who have sickle cell disease and a case report on association with systemic lupus erythematosus (SLE) $(8,9,10)$ This study is intended to review existing records of patients who had AVN of the head of femur, describe their characteristics, radiological severity of the condition at presentation and associated aetiological risk factors

\section{MATERIALS AND METHODS}

This is a retrospective study of consequtive patients that were managed for osteonecrosis of the head of femur in a tertiary hospital. All patients with the diagnosis of osteonecrosis, avascular necrosis or aseptic necrosis of the head of femur were identified from the orthopaedic consultant outpatient clinic registers for the study period. Their personal information, including hospital numbers were extracted and thereafter used to identify and retrieve their case files from the medical information department of the study centre.

Each case file was studied, and data extracted onto a proforma designed for the purpose. Information on personal data, history, diagnosis, imaging studies results, and laboratory investigations were extracted. No age group was exempted from the study.

During the study period, patients with known or suspected osteonecrosis were referred to the orthopaedic clinic. After clinical assessment, each patient had radiographic examination of both hips. Complete blood count and haemoglobin genotype were also done. Magnetic resonance imaging was not routinely available. All were given analgesics until diagnosis was confirmed when definitive treatment was offered.

Data was computerized and analysed using Epiinfo version 7 (Centers for Disease Control, USA), generating simple frequencies, averages and charts. Categorical variables were compared by Chi square test with level of significance at $\mathrm{p}<0.05$.

The study was approved by the scientific and ethics review committee of the study centre (OOUTH-HREC).

\section{RESULTS}

During the study period (January 2013 to January 2019), twenty nine patients presented with osteonecrosis $(\mathrm{ON})$ of the head of femur while 32 hips were affected. There were 16 females and 13 males (M:F $=1: 1.2)$. As shown in table 1, their ages range from 9 years to 67 years. Their mean age is $26.6 \mathrm{yrs} \pm 13.3$. The mean age of the male patients is $29.3 \mathrm{yrs} \pm 16.8$ while that of the female patients is $24.3 \mathrm{yrs} \pm 9.7$. The mean age of patients with SCD (HbSS and HbSC) is 17.5 years (range 9-28years) while that of those with $\mathrm{HbAA}$ is 28.6 years (range $11-41$ years). The mean body mass index (BMI) is $21.9 \pm 5.2$ (range 14 - 31.6). There is no significant difference between the mean BMI of both genders (21.4 vs $22.3, p=0.74)$

Twenty six patients $(89.7 \%)$ presented with unilateral ON while $3(10.3 \%)$ had bilateral affectation (table 2). Record of haemoglobin genotype was available for 20 of the patients. As shown in table 3, most of them, 9, have HbSS. Seven others have $\mathrm{HbAA}, 2 \mathrm{HbAS}$ and $2 \mathrm{HbSC}$. There is no significant difference in the frequency of hip pain and the bilaterality in the different haemoglobin genotype groups. When bilaterality 
is compared in the group with $\mathrm{HbAA}$ and the other genotypes, there is also insignificant difference, $p=0.64$. All the patients with bilateral affectation were in the atraumatic group. Also, gender did not affect bilaterality, $\mathrm{p}=0.7$.

The most common radiographic stage of the $\mathrm{ON}$ at presentation is Ficat and Arlet stage 3. This was seen in 20 of the affected 32 hips $(62.5 \%)$. Nine hips $(28.1 \%)$ were at stage 4,2 hips $(6.3 \%)$ were stage 2 and only one hip (3.1\%) was stage 1 . Figure 1 . That is, $90.6 \%$ of the patients at presentation, had severe radiographic ON (stages 3 and 4) while 19.4\% had moderate presentation.

The duration of hip pain at presentation was 1 to 120 months (mean 23.9months \pm 30.6 ). The modal duration of presentation is 6 months. The risk factors for ON in this cohort of patients are abnormal genotype $(\mathrm{n}=13 ; 44.8 \%)$ cerebrovascular accident (CVA) in 1 (3.4\%) patient and trauma in 4 patients $(13.8 \%)$, Figure 2. Trauma was due to fall and being knocked down by a motor vehicle (VPA) in 2 patients each. Eleven patients (37.7\%) had idiopathic ON.

\section{DISCUSSION}

Osteonecrosis is commonly described affecting the head of femur in patients with sickle cell disease. There are no population studies of the prevalence of this condition and epidemiological characteristics of the condition has not been described for the Nigerian patients in general.

The age group of presentation that is often reported is 30 to 60 years $(1,3,11)$. From India, Vardhan et al reported a mean age of 34.7 years, range 14-70 (12). From Japan, Kubo et al reported mean ages of $30 \mathrm{~s}$ and 40 s for male and female patients (13). Lamb et al (11) reported a mean age 58years at presentation in the UK. However, Adesina et al (14) reported a mean age of 27 years for SCD patients in California.

The mean age at presentation in this report, 26.6 years, is similar to that in the report of Adesina et al but younger than the mean age reported from Indian patients, 34.7years (12) and 30 to 40 years in Japanese series (13). From Nigeria, Akinyoola had reported a mean age of 23.7years from a series of patients with sickle cell disease (9). Iwegbu and Fleming in 1989 reported a series of 29 patients with sickle cell disease and 34 affected hips (15). The patients were as young as in our report, with an age range of 6years to $15 y e a r s$. In a series of 24 patients with SCD and ON from Brazil, described by Matos et al (7), 8years was the youngest age of their patients.
While $17 \%$ of their patients (Iwegbu and Fleming) had bilateral hip affectation, this was seen in $10.3 \%$ of our patients. This contrasts sharply with $86.7 \%$ bilaterality from a series of SCD patients from Brazil (4). Young patients are generally affected most often but these patients are even younger in areas like Nigeria and Brazil where the prevalence of sickle cell disease is high. The affected patients from Nigeria are younger, probably because of haemoglobinopathy (9) being the most common associated factor as shown in this report. As we observed in this report also, it is possible that patients with SCD develop ON at a younger age (adolescence) compared to others who tend to develop this condition in early adulthood.

Male preponderance is usually reported for $\mathrm{ON}$ of the head of femur (5). The report from India indicated five times more prevalence in males than females but a $\mathrm{M}: \mathrm{F}$ ratio of $5: 4$ in Japan. There is no significant difference in the affectation of the genders in our patients although a slight female preponderance exists at M:F 1:1.2. There is a slight preponderance of females being affected from Nigeria. A M:F of 1:1.2 in our report and 1:1.6 from the report of Iwegbu and Fleming. There may be a reason for this observation that is still unclear.

Late presentation is seen in this report where $90.6 \%$ of the patients presented with radiographic stages 3 and 4 . This is similar to the observation of Akinyoola et al in a series of $\mathrm{ON}$ in patients with sickle cell disease where $81.8 \%$ presented with stages 3 and 4, Ficat \& Arlet (10). Symptoms and clinical signs of ON are not specific, hence making the diagnosis early is difficult. A high index of suspicion is required to make the diagnosis early. A deliberate policy of early MRI screening of the hips, even though relatively very expensive, is required to make early diagnosis so as to be able to institute treatment aimed at preventing progression to collapse of the head of femur. An obvious challenge to achieving this is late presentation. The average duration of symptoms of hip pain at presentation in our patients is 2years. Strategies for early diagnosis is needed especially in patients with sickle cell disease.

In reports from Europe, North America and Asia, the most common associated factors are chronic alcoholism and use of steroids $(5,12,13)$. Rates of $35 \%$ to $51 \%$ are reported for steroid use while $20 \%$ to $31 \%$ are reported for alcohol abuse. This is unlike in Nigeria where sickle cell disease appears to be the most common cause. This also explains the younger age of our patients who are 
born with abnormal haemoglobin genotype especially HbSS and HbSC. The Sickle cell trait is most common in Nigeria, present in $25 \%$ of the population (16), and sickle cell disease affects $1-$ 3 percent of the population (17). This explains the preponderance of haemoglobinopathy as the cause in our patients. It is possible that alcohol abuse and steroid use are not as common in our patients as in Asians and Caucasians. There may be no significant difference in the clinical features of the disease in patients with $\mathrm{HbSS}$ and $\operatorname{HbSC}(4)$.

Endothelial dysfunction, leading to cardiovascular and cerebrovascular events is an important, although uncommon cause of $\mathrm{ON}$ (18). Only one case, of cerebrovascular accident, was found in our patients.

\section{CONCLUSIONS}

Osteonecrosis of the head of femur occurs more often in young patients. The disease is more often unilateral, and majority of patients presents late, with collapse of the head of femur. Abnormal haemoglobin genotype, especially $\mathrm{HbSS}$ is the most common associated risk factor followed by idiopathic cases.

Conflict of interest: All authors declare that they have no conflict of interest

\section{REFERENCES}

1. Hernigou P, Daltro G, Hernigou J. Hiposteonecrosis: stem cells for life or behead and arthroplasty? Int Orthop 2018; 42:1425 1428

2. Petek D, Hannouche D, Suva D. Osteonecrosis of the femoral head: pathophysiology and current concepts of treatment. EFFORT Open Rev 2019; 4(3): $85-97$

3. Gun BK, Frank RM, Gratton RW, Bader JO, Kusnezov N, Orr JD, et al. Non modifiable risk factors associated with avascular necrosis in the US military. Mil Med 2019; jun 11. Pii. Usz128. doi: 10.1093/milmed/usz128 [Epub ahead of print]

4. Daltro G, Franco BA, Faleiro TB, Rosario DAV, Daltro PB, Fortuna V. Osteonecrosis in sickle cell disease patients from Bahia, Brazil: a crosssectional study. Int Orthop 2018; 42(7):1527 1534

5. Kaushik AP, Das A, Cui Q. Osteonecrosis of the femoral head: An update in year 2012. World J Orthop 2012; 3(5): 49-57
6. Osawa Y, Seki T, Tagegami Y, Kasai T, Higuchi Y, Ishiguro N. Do femoral head collapse and the contralateral condition affect patient-reported quality of life and referral pain in patients with osteonecrosis of the femoral head. Int Orthop 2018; 42: $1463-1468$

7. Matos MA, SiLva LLDS, Alves GB, de Alcantara WS, Velga D. Necrosis of the femoral head and health related quality of life of children and adolescents. Acta Ortop Bras 2018; 26(4): 227 230

8. Adelowo OO, Oguntona S. Avascular necrosis of femoral head associated with connective tissue disease in Nigerians: case series. West Afr J Med 2009; 28: $262-265$

9. Akinyoola AL, Adediran IA, Asaleye CM, Bolarinwa AR. Risk factors for osteonecrosis of the femoral head in patients with sickle cell disease. Int Orthop 2009; 33: 923 - 926

10. Akinyoola AL, Adediran IA, Asaleye CM. Avascular necrosis of the femoral head in sickle cell disease in Nigeria: a retrospective study. Niger Postgrad Med J 2007; 14: 217 - 220

11. Lamb JN, Holton C, O'Connor P, Giannoudis PV. Avascular necrosis of the hip. BMJ 2019; 365: 12178

12. Vardhan H, Tripathy SK, Sen RK, Aggarwal S, Goyal T. Epidemiological profile of femoral head osteonecrosis in the North Indian population. Indian J Orthop 2019; 52: 140 - 146

13. Kubo T, Ueshima K, Salto M, Ishida M, Aral Y, Fujiwara H. Clinical and basic research on steroid-induced osteonecrosis of the femoral head in Japan. J Orthop Sci 2016; 21: 407413

14. Adesina O, Brunson A, Keegan THM, Wun T Osteonecrosis of the femoral head in sickle cell disease: prevalence, comorbidities and surgical outcomes in California. Blood Adv 2017; 1(16): $1287-1295$

15. Iwegbu CG, Fleming AF. Avascular necrosis of the femoral head in sickle-cell disease. A series from the Guinea Savannah of Nigeria. J Bone joint Surg Br 1985; 67(1): 29-32

16. Akinyanju OO. A profile of sickle cell disease in Nigeria. Ann NY Acad Sci 1989; 565: 126-136

17. Emechebe GO, Onyire NB, Orji ML, Achigbu KI. Sickle cell disease in Nigeria-A review. IOSR Journal of Dental and Medical Sciences 2017; 16(1): $87-94$

18. Sung PH, Yang YH, Chianh HJ, Chiang JY, Chen CJ, Yip HK, Lee MS. Cardiovascular and cerebrovascular events are associated with nontraumatic osteonecrosis of the femoral head. Clin Orthop Relat Res 2018; 476(4): 865-874 
Table 1. Characteristics of 29 patients with hip osteonecrosis

\begin{tabular}{llll}
\hline Variable & \multicolumn{3}{l}{ Frequency } \\
\hline Sex & Female & 16 & \\
Age & Male & 13 & $55.2 \%$ \\
& & & \\
& Mean & $26.6 \pm 13.3$ years & \\
BMI & Range & $9-67$ years & \\
& & & \\
& Mean & $21.9 \pm 5.2$ & \\
Duration of hip pain & Range & $14-31.6$ & \\
& & & \\
& Mean & $25.1 \pm$ months \\
& Range & $1-120$ months \\
Affected side & Mode & 6 months \\
& & & \\
& Unilateral & 26 patients \\
& Bilateral & 3 patients \\
\hline
\end{tabular}

Table 2. Comparison of gender for affected sides and body mass index

\begin{tabular}{llllll}
\hline Variable & & Male & Female & Total & \\
\hline Affected side & Unilateral & 12 & 14 & 26 & \\
& Bilateral & 1 & 2 & 3 & $\mathrm{p}=0.68$ \\
Body mass index & & & & & \\
& Mean & 21.4 & 22.3 & & $\mathrm{p}=0.74$ \\
\hline
\end{tabular}

Table 3. Frequency of genotype, affected side and hip pain in 20 patients

\begin{tabular}{|c|c|c|c|c|c|c|}
\hline & Affected side & & & & & \\
\hline Genotype & Bilateral & Unilateral & & & & \\
\hline $\mathrm{AA}$ & 1 & 6 & & & & \\
\hline AS & 0 & 2 & & & & \\
\hline $\mathrm{SC}$ & 0 & 2 & & & & \\
\hline SS & 1 & 8 & $\mathrm{p}=0.89$ & & & \\
\hline Total & 2 & 18 & & & & \\
\hline & Left Hip Pain & & & Right Hip Pain & & \\
\hline Genotype & No & Yes & & No & Yes & \\
\hline $\mathrm{AA}$ & 2 & 5 & & 4 & 3 & \\
\hline AS & 1 & 1 & & 1 & 1 & \\
\hline $\mathrm{SC}$ & 1 & 1 & & 1 & 1 & \\
\hline $\mathrm{SS}$ & 1 & 8 & & 4 & 5 & \\
\hline Total & 8 & 12 & $\mathrm{p}=0.89$ & 10 & 10 & $\mathrm{p}=0.97$ \\
\hline
\end{tabular}




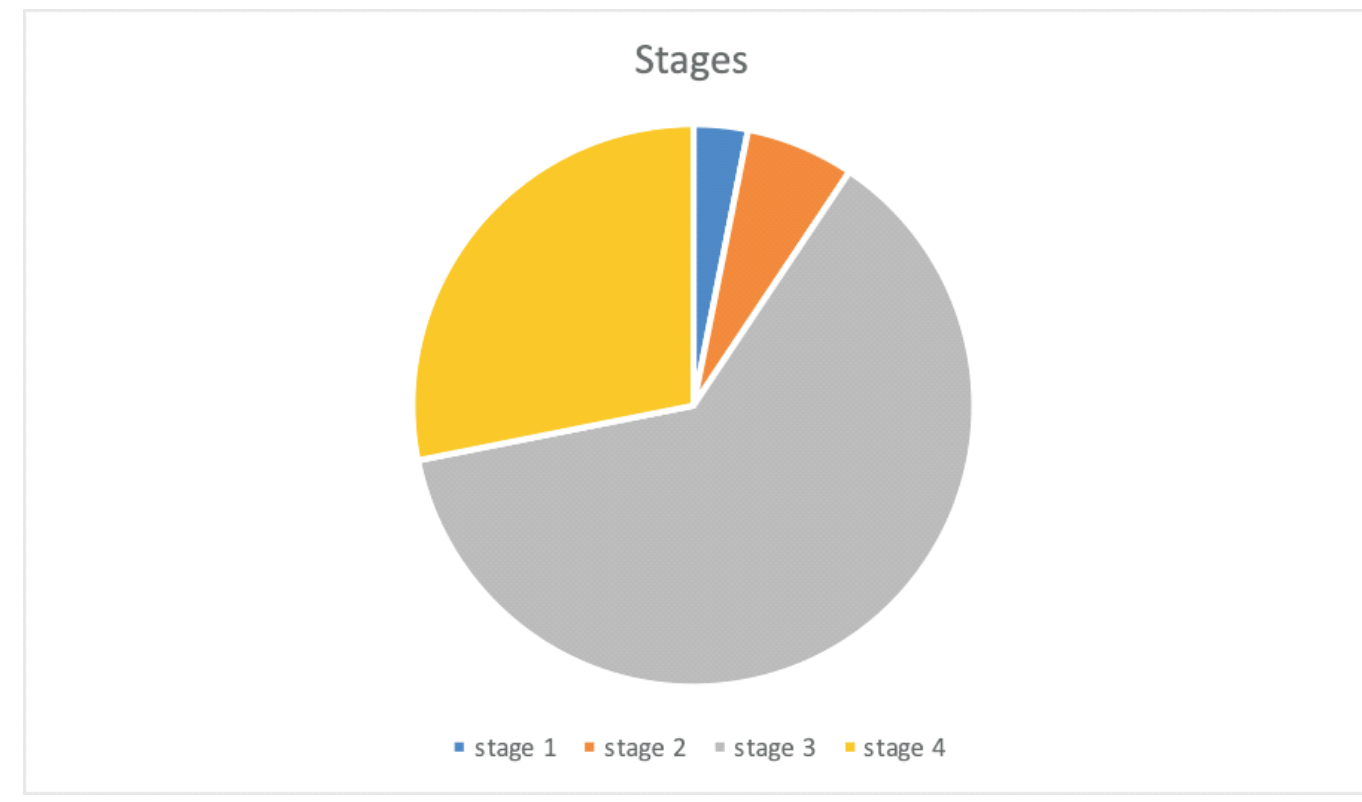

Figure 1. Ficat and Arlet radiographic stages of affected hips

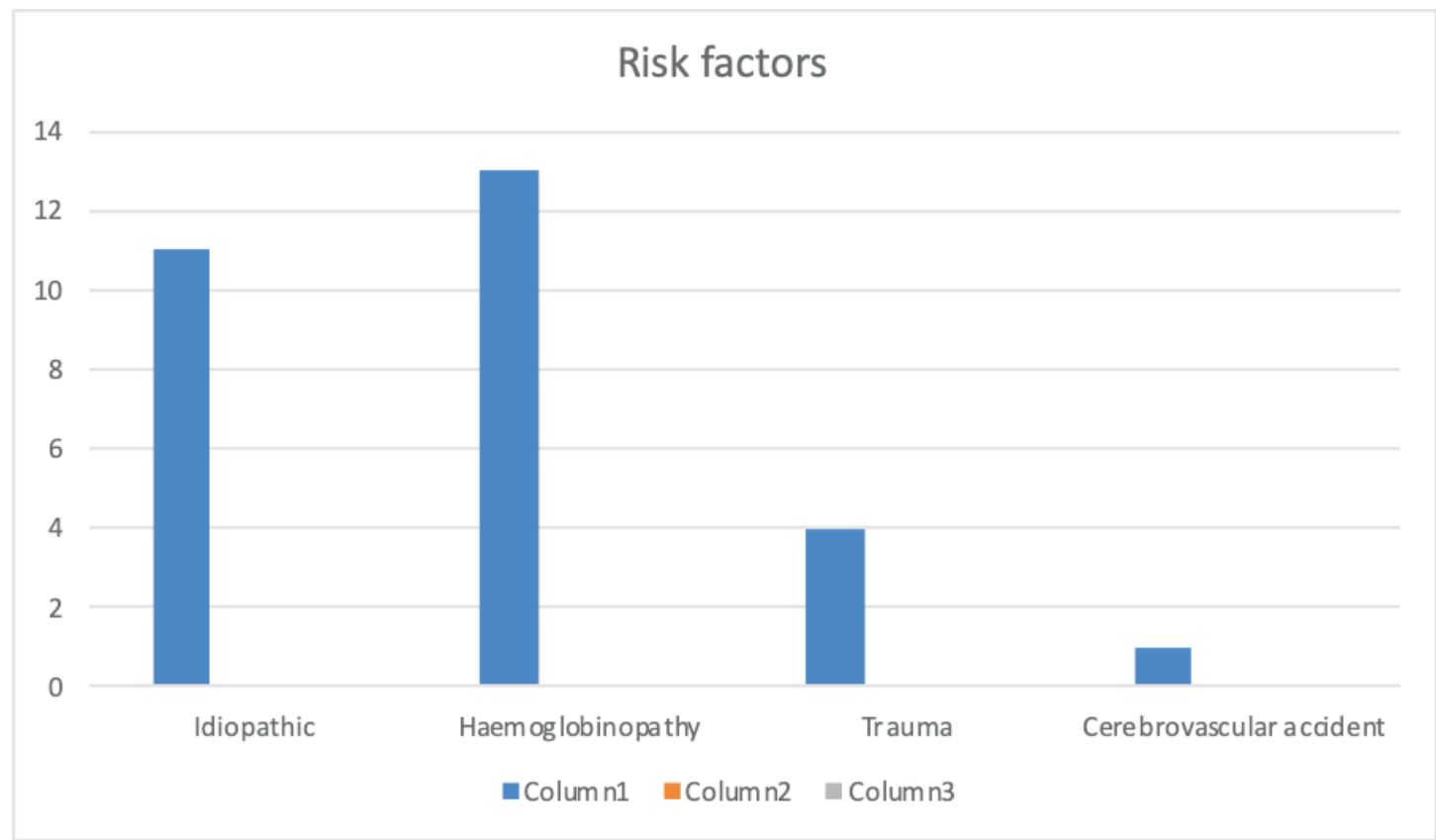

Figure 2. Associated risk factors for osteonecrosis of the head of femur 